PROFESI, Volume 14, Nomor 1, September 2016

\title{
HUBUNGAN ANTARA MOTIVASI BELAJAR DAN LATAR BELAKANG PENDIDIKAN DENGAN PRESTASI BELAJAR MAHASISWA
}

\author{
THE CORRELATION BETWEEN THE LEARNING MOTIVATION \\ AND THE EDUCATION BACKGROUND WITH THE ACHEIVEMENT \\ OF ACADEMIC OF STUDENT
}

\begin{abstract}
Anton Yuliawan
Akper Patria Husada Surakarta

yuliawan_anton@yahoo.com

Abstrak

Hubungan Antara Motivasi Belajar dan Latar Belakang Pendidikan dengan Prestasi Belajar Mahasiswa di Akademi Keperawatan Patria Husada Surakart. Tujuan Penelitian: (1) Adakah hubungan antara motivasi belajar dengan prestasi belajar mahasiswa (2) Adakah hubungan antara latar belakang pendidikan dengan prestasi belajar mahasiswa (3) Adakah hubungan antara motivasi belajar dan latar belakang pendidikan dengan prestasi belajar mahasiswa di Akademi Keperawatan Paria Husada Surakarta. Desain penelitian yang digunakan adalah deskriptif korelatif. Teknik sampling adalah total sampling. Teknik pengumpulan data meliputi: observasi, wawancara dan angket, sedangkan tehnik analisis data menggunakan Logistik Regresi. Hasil Penelitian: Variabel X1 (motivasi) dan variable X2 berpengaruh signifikan terhadap prestasi belajar mahasiswa $(Y)$ karena masing-masing variabel independent mempunyai nilai $P$ value < 0,05. Dari persamaan logistic regression didapat bahwa log off odds prestasi belajar (Y) akan lebih tinggi secara positif berhubungan dengan motivasi belajar siswa (X1) dan latar belakang pendidikan (X2). Setiap unit kenaikan motivasi belajar (X1) akan meningkatkan log of odds prestasi belajar sebesar 2,401 dan setiap unit perubahan latar belakang pendidikan (X2) akan meningkat log of odds prestasi belajar sebesar 1,937. Kesimpulan Penelitian: (1) Ada hubungan antara motivasi belajar dengan prestasi belajar mahasiswa, berarti bahwa makin tinggi motivasi belajar mahasiswa maka makin tinggi pula pencapaian prestasi belajarnya, (2) Ada hubungan antara latar belakang pendidikan dengan prestasi belajar mahasiswa, hal ini menggambarkan bahwa pendidikan SMA khususnya jurusan IPA memberikan kontribusi besar terhadap pencapaian prestasi yang lebih memuaskan, (3) Ada hubungan antara motivasi belajar dan latar belakang pendidikan dengan prestasi belajar mahasiswa di Akademi Keperawatan Patria Husada Surakarta, diartikan bahwa motivasi belajar yang tinggi dan didukung dengan latar belakang pendidikan SMA khususnya IPA memberikan kontribusi yang besar terhadap pencapaian prestasi belajar mahasiswa yang tinggi di Akademi Keperawatan Patria Husada Surakarta.
\end{abstract}

Kata kunci: Motivasi belajar, Latar belakang pendidikan, Prestasi belajar

\begin{abstract}
The Correlation Between The Learning Motivation And The Education Background with The Acheivement of Academic of Student At The Patria Husada of Nursing Academiy of Surakarta. The objective of the research is are there any correlation between the learning motivation and the background of the education with the learning acheivement of academic student at the Patria Husada of Nursing Academy of Surakarta. The Research Design was Correlative Descriptive. The technic sampling was total sampling. The technic of collecting data extended: observation, dialoque and quistionaire. The technic analisys of the data, used was the logistic regression. The result of the research,showed that variable learning motivation and the background of education had significant influence to the acheivement of academic student with each independent variable learning motivation has significant 0.028 and the background of education has significant 0.039 ( $p$
\end{abstract}


value < 0.05). From the equetation of the regression of the logistic found that every unit of the increasing motivation will increase log of odds achievement 2.401 with expected 11,032. and every unit increasing of the education background will increase log of odds achievement 1.937 with expected 6.935. The conclusion of researche,there is the correlation between the learning motivation and the background of the education with the acheivement of academic student at the Patria Husada Nursing Academy Surakarta. It's mean the high learning motivation with the background of education gived more the learning achievement of academic student at Nursing Academic of Paria Husada Surakarta.

Key words: Learning Motivation, The Background of The Education, Learning Acheivement.

\section{PENDAHULUAN}

Latar belakang pendidikan masuk pada sebuah jurusan di perguruan tinggi merupakan modal utama dalam mengikuti dan memahami mata kuliah tertentu apalagi pendidikan tersebut berkaitan dengan mata kuliah keahlian tertentu.

Di institusi pendidikan kesehatan sejak tahun 2005 menerapkan sistem penyaringan dengan mengambil latar belakang pendidikan calon mahasiswa baru adalah pendidikan lanjutan setingkat Sekolah Menengah Atas dan sederajat. Dimana dasar pendidikan tersebut adalah berasal dari SMA atau SMU, MAN, SMK dan MAN Kejuruan. Tingkatan sekolah tersebut mempunyai beberapa jurusan antara lain SMA dan MAN mempunyai tiga jurusan yaitu IPA, IPS, dan Bahasa. Pada pendidikan SMK sendiri terbagi dalam dua kelompok yaitu SMK Kesehatan dan SMK non Kesehatan. SMK Kesehatan mempunyai beberapa jurusan antara lain bidang farmasi, analis kesehatan. Pendidikan SMK non kesehatan mempunyai beberapa jurusan antara lain akuntansi, perkantoran, tata boga, tata busana, pariwisata, mesin, otomotif, elektro, listrik, bangunan, kimia industri.

Jenjang pendidikan yang mempunyai kurikulum pendidikan dengan materi pengajaran ilmu pengetahuan alam sangat mendukung keberhasilan proses pendidikan di Akademi Keperawatan yaitu jenjang SMA, SMK Kesehatan dan SMK Kimia Industri. Namun demikian di Akademi Keperawatan patria Husada Surakarta sejak diterbitkannya Pedoman Seleksi Penerimaan Siswa dan Mahasiswa Baru tahun 2000, menerima calon mahasiswa baru dengan latar belakang pendidikan SMA dan SMK segala jurusan.

Di sisi lain keberhasilan pendidikan juga dipengaruhi oleh motivasi dari calon mahasiswa itu sendiri. Meskipun tidak pernah mendapatkan mata pelajaran ilmu pengetahuan alam pada saat menempuh pendidikan menengah atas tetapi mereka sudah pernah mendapatkan mata pelajaran tersebut pada saat menempuh pendidikan di SMP (Sekolah Menengah Pertama). Sehingga keberhasilan mahasiswa yang menempuh pendidikan tinggi di Akademi Keperawatan dapat mencapai hasil yang memuaskan. Hal ini dimungkinkan karena minat dan motivasi mahasiswa untuk belajar ilmu keperawatan tinggi sehingga mereka dapat mencapai prestasi yang dikehendaki.

Dari data yang di diperoleh dari Akademi Keperawatan Patria Husada Surakarta bahwa jumlah mahasiswa yang berlatar belakang pendidikan SMA dengan jurusan IPA $=33,05 \%$, SMA dengan jurusan non IPA $=50,85 \%$, sedangkan SMK Kesehatan $=0 \%$ dan SMK non kesehatan sebanyak $=16,10 \%$. Dari jumlah keseluruhan mahasiswa yang berprestasi (nilai $\geq$ 3,50 ) dengan kualifikasi SMA IPA $=3,39 \%$ dan SMK $=3,39 \%$. Pada tahun akademi 2010/2011, pendaftar yang diterima sebagai mahasiswa dengan berlatar belakang pendidikan SMA jurusan IPA $=28,57 \%$, SMA jurusan IPS $=57,14$ $\%$, SMK non kesehatan $=14,29 \%$ dan SMK kesehatan $=0 \%$ (Akper Patria Husada, 2010)

Menurut Slameto (2003) bahwa prestasi seseorang dipengaruhi oleh faktor eksternal dan faktor internal dari individu. Faktor eksternal antara lain (1) latar belakang pendidikan orang tua, dengan pendidikan yang tinggi anak dituntut untuk mencapai prestasi yng lebih baik, (2) status ekonomi keluarga, dengan status ekonomi yang baik kebutuhan pokok anak akan terpenuhi dengan baik sehingga kesehetan juga akan baik pula, (3) ketersediaan sarana dan prasarana baik di sekolah maupun di rumah, dengan sarana dan prasarana yang memadai maka tujuan belajar akan lebih terpenuhi, (4) media belajar yang 
dipakai guru, dengan media pembelajaran yang baik tingkat pemahaman anak didik juga akan lebih baik, (5) kompetensi guru, menentukan baik tidaknya program pengjaran sehingga akan melahirkan metode pembelajaran yang baik. Sedangkan faktor internal antara lain (1) kesehatan, individu yang sehat akan lebih baik dalam belajar dibandingkan yang kurang sehat, (2) kecerdasan, individu yang mempunyai kecerdasan yang tinggi maka prestasi belajarnya juga akan lebih tinggi dibandingkan yang tingkat kecerdasannya lebih rendah (3) cara belajar, tehnik belajar yang baik akan memberikan tingkat pemahaman yang lebih baik, (4) bakat, orang akan lebih berhasil jika belajar sesuai dengan bakatnya, (5) minat, minat yang tinggi akan menghasilkan prestasi yang lebih baik dan (6) motivasi individu itu sendiri, faktor internal individu sksn mendasari dalam mencapai prestasi yang diinginkan meskipun faktor eksternal juga sangat berpengaruh dalam mencapai tujuan yang diinginkan. Namun demikian pengalaman belajar juga merupakan suatu hal yang penting sebagai dasar dalam memahami mata pelajaran yang sedang ditempuhnya. Pengalaman belajar akademik ini dapat diperoleh sejak seseorang menempuh pendidikan dari tingkat dasar dan menengah bahkan pada saat seseorang menempuh pendidikan diperguruan tinggi.

Menurut Mc. Donald dalam Sardiman (2007): Motivasi adalah perubahan energi dalam diri seseorang yang ditandai dengan munculnya "feeling" dan didahului dengan tanggapan terhadap adanya tujuan. Dari pengertian motivasi yang dikemukakan oleh Mc. Donald ini mengandung tiga elemen penting, yaitu: 1) Motivasi mengawali terjadinya perubahan energi pada diri setiap individu manusia, 2) Motivasi ditandai dengan munculnya "rasa/feeling", afeksi seseorang, 3) Motivasi akan terangsang karena adanya tujuan.

Menurut Santrock (2010), motivasi adalah proses yang memberi semangat, arah, dan kegigihan perilaku. Artinya, perilaku yang memiliki motivasi adalah perilaku yang penuh energi, terarah, dan bertahan lama. Dalam kegiatan belajar, maka motivasi dapat dikatakan sebagai keseluruhan daya penggerak di dalam diri mahasiswa yang menimbulkan kegiatan belajar, yang menjamin kelangsungan dari kegiatan belajar dan memberikan arah pada kegiatan belajar, sehingga tujuan yang dikehendaki oleh subyek belajar itu dapat tercapai.
Sartain dalam bukunya Psychology Understanding of Human Behavior: Motif adalah suatu pernyataan yang kompleks di dalam suatu organisme yang mengarahkan tingkah laku/ perbuatan ke suatu tujuan atau perangsang (Purwanto, 2007)

Setiap individu memiliki kondisi internal, dimana kondisi internal tersebut turut berperan dalam aktivitas dirinya sehari-hari. Salah satu dari kondisi internal tersebut adalah "motivasi". Motivasi adalah dorongan dasar yang menggerakan seseorang bertingkah laku. Dorongan ini berada pada diri seseorang yang menggerakan untuk melakukan sesuatu yang sesuai denga dorongan dalam dirinya. Oleh karena itu, perbuatan seseorang yang didasarkan atas motivasi tertentu mengandung tema sesuai dengan motivasi yang mendasarinya. Istilah motivasi yang berasal dari kata motif, dapat diartikan sebagai kekuatan yang terdapat dalam diri individu, yang menyebabkan individu tersebut bertindak atau berbuat. Motif tidak dapat diamati secara langsung. Tapi dapat diinterpretasikan dalam tingkah laku (Uno, 2006).

Macam atau jenis motivasi dapat dilihat dari berbagai sudut pandang, maka dari itu penggolongan motivasipun sangat bervariasi. Motivasi dilihat dari dasar pembentukannya yaitu: Motivasi bawaan, adalah motif yang dibawa sejak lahir tanpa dipelajari. Sebagai contoh adalah: dorongan untuk makan, minum, bekerja, istirahat, seksual, dan lain-lain. Motivasi ini sering disebut motif biologis atau motif physiological drive. Berikutnya adalah motivasi yang dipelajari adalah motif-motif yang timbul karena dipelajari. Sebagai contoh adalah: dorongan untuk belajar, dorongan untuk mengajar di masyarakat, dan lain-lain. Motivasi ini sering disebut social motives.

Jenis motivasi menurut Frandsen dalam Ellys Tamrin (2005): 1) Cognitive motives, yatu motif ini merujuk pada gejala instrinsic, yaitu menyangkut kepuasan individual. Kepuasan individu yang berada di dalam diri manusia dan biasanya berujud proses dan produk mental. Jenis motif seperti ini adalah sangat primer dalam kegiatan belajar, terutama yang berkaitan dengan pengembangan intelektual, 2) Self - expressio, penampilan diri adalah sebagian dari perilaku manusia, untuk itu memang diperlukan kreativitas dan daya imajinasi, sehingga individu mampu membuat suatu keajaiban. Jadi dalam hal ini seseorang memiliki keinginan untuk aktuali- 
sasi diri, 3) Self - enhancement, melalui aktualisasi diri dan pengembangan kompetensi akan meningkatkan kemajuan diri seseorang, kemajuan diri ini menjadi salah satu keinginan bagi setiap individu. Dalam belajar dapat diciptakan suasana kompetensi yang sehat bagi peserta didik untuk mencapai suatu prestasi.

Motivasi sangatlah penting bagi seseorang untuk menentukan tindakan seseorang dalam meraih sesuatu yang diinginkan karena akan memberikan kekuatan pada diri individu. Motivasi sangat berpengaruh terhadap ketahanan dan ketekunan belaja (Uno, 2009).

Terdapat dua aspek utama dalam motivasi belajar yaitu: a. Motivasi ekstrinsik, yaitu melakukan sesuatu untuk mendapatkan sesuatu yang lain. Motivasi ekstrinsik sering dipengaruhi oleh insentif eksternal seperti imbalan dan hukuman. Misalnya, murid belajar keras untuk mendapatkan nilai yang baik, b. Motivasi intrinsik, yaitu motivasi internal untuk melakukan sesuatu demi sesuatu itu sendiri. Misalnya, murid belajar menghadapi ujian karena dia senang pada mata pelajaran yang diujikan itu.

Motivasi dan belajar merupakan dua hal yang saling mempengaruhi. Belajar adalah perubahan tingkah laku yang relatif permanen dan secara potensial terjadi sebagai hasil dari praktek atau penguatan (reinforced practice) yang dilandasi maksud untuk mencapai tujuan tertentu. Motivasi belajar dapat timbul karena faktor intrinsik, berupa hasrat dan keinginan berhasil, dan dorongan kebutuhan belajar, serta harapan akan cita-cita. Sedang faktor ekstrinsiknya adalah adanya penghargaan, lingkungan belajar yang kondusif, dan kegiatan belajar yang menarik. Kemampuan motivasi adalah kemampuan untuk memberikan semangat kepada diri sendiri guna melakukan sesuatu yang baik dan bermanfaat. Dalam hal ini terkandung adanya unsur harapan dan optimisme yang tinggi, sehingga memiliki kekuatan semangat untuk melakukan sesuatu aktifitas tertentu, misalnya dalam hal belajar. Itulah yang disebut dengan motivasi belajar (Sari, 2004).

Hakikat motivasi belajar adalah dorongan internal dan ekternal pada mahasiswa yang sedang belajar untuk mengadakan perubahan tingkah laku, pada umumnya dengan beberapa indikator atau unsur yang mendukung. Hal ini mempunyai peranan besar dalam keberhasilan seseorang dalam belajar. Indikator motivasi belajar dapat diklasifikasikan sebagai berikut: adanya hasrat dan keinginan berhasil, adanya dorongan dan kebutuhan dalam belajar, adanya harapan dan cita-cita masa depan, adanya penghargaan dalam belajar, adanya kegiatan yang menarik dalam belajar, adanya lingkungan belajar yang kondusif, sehingga memungkinkan mahasiswa dapat belajar dengan baik (Uno, 2009).

Jenjang pendidikan adalah tahapan pendidikan yang ditetapkan berdasarkan tingkat perkembangan peserta didik, tujuan yang akan dicapai, dan kemampuan yang dikembangkan. Pendidikan di Indonesia mengenal tiga jenjang pendidikan, yaitu pendidikan dasar (SD/MI/Paket A dan SLTP/MTs/Paket B), pendidikan menengah (SMU/SMK/Paket C), dan pendidikan tinggi. Meski tidak termasuk dalam jenjang pendidikan, terdapat pula pendidikan anak usia dini, pendidikan yang diberikan sebelum memasuki pendidikan dasar.

Pendidikan menengah merupakan lanjutan pendidikan dasar, terdiri atas pendidikan menengah umum dan pendidikan menengah kejuruan. Pasal 18 ayat 2 Undang-undang No 20 tahun 2003 bahwa Pendidikan menengah berbentuk Sekolah Menengah Atas (SMA), Madrasah Aliyah (MA), Sekolah Menengah Kejuruan (SMK), dan Madrasah Aliyah Kejuruan (MAK), atau bentuk lain yang sederajat (Sairin, 2010).

Latar belakang pendidikan yang diterima menurut petunjuk pelaksanaan sistem penerimaan siswa dan mahasiswa baru tahun 2010 untuk jenjang pendidikan tinggi adalah sekolah (SMU) dan sekolah menengah kejuruan (SMK), Madrasah Aliyah atau yang sederajat (Pusdiknakes, 2010). Diartikan bahwa latar belakang pendidikan yang diterima mendaftar adalah semua jenjang pendidikan menengah termasuk didalamnya adalah pendidikan kejuruan non kesehatan.

Belajar adalah suatu kegiatan yang dilakukan dengan melibatkan dua unsur, yaitu jiwa dan raga. Belajar adalah serangkaian kegiatan jiwa dan raga untuk memperoleh perubahan tingkah laku sebagai hasil dari pengalaman individu dalam interaksi dengan lingkungan yang menyangkut aspek kognitif, afektif, dan psikomotorik. Gerak raga yang ditunjukkan harus sejalan dengan proses jiwa untuk mendapatkan perubahan (Syaiful, 2002). Sedangkan menurut Slameto (2003) belajar sebagai suatu proses usaha yang dilakukan seseorang untuk memperoleh suatu perubahan 
tingkah laku yang secara keseluruhan, sebagai hasil pengalamannya sendiri dalam interaksi dengan lingkungannya.

Berdasarkan keterangan di atas, dapat disimpulkan bahwa belajar adalah serangkaian kegiatan jiwa raga untuk memperoleh suatu perubahan tingkah laku. Prestasi belajar merupakan wujud yang menggambarkan usaha belajar yang melibatkan interaksi antara guru dan siswa, ataupun orang lain dan lingkungannya. Dari pengertian ini dapat dikatakan bahwa prestasi belajar adalah hasil yang dicapai siswa setelah melalui proses belajar yang mencerminkan prestasi belajar yang dalam periode tertentu.

Belajar merupakan proses yang menimbulkan terjadinya perubahan atau pembaharuan dalam tingkah laku atau kecapakan. Jadi berhasil tidaknya seseorang dalam proses belajar tergantung dari faktor-faktor yang mempengaruhinya. Menurut faktor-faktor yang mempengaruhi prestasi belajar dapat digolongkan dalam dua bagian, yaitu faktor internal dan faktor eksternal. Faktor eksternal adalah faktor yang mempengaruhi prestasi belajar yang berasal dari luar diri siswa. Faktor-faktor eksternal itu antara lain: Latar belakang pendidikan orang tua, status ekonomi sosial orang tua, ketersediaan sarana dan prasarana di rumah dan sekolah, media yang di pakai guru, kompetensi guru,

Sedangkan faktor internal adalah faktor yang mempengaruhi pretasi belajar yang berasal dari dalam diri siswa. Faktor-faktor internal itu antara lain: Kesehatan jasmani dan rohani, kecerdasan/intelegensia, cara belajar, bakat, minat, motivasi.

\section{DESAIN PENELITIAN}

Desain penelitian ini adalah deskriptif korelatif. Tempat penelitian ini dilaksanakan di lingkungan Kampus Akademi Keperawatan Patria Husada Surakarta dengan alamat jalan Sumpah Pemuda no 50 Mojosongo Surakarta. Penelitian dilaksanakan sejak pembuatan proposal sampai dengan selesai yaitu bulan Pebruari 2011 s.d. Mei 2011 pada mahasiswa tingkat I semester II Akademi Keperawatan Patria Husada Surakarta tahun akademik 2010 / 2011.

Populasi dalam penelitian ini adalah mahasiswa tingkat I semester II dengan jumlah mahasiswa 70 orang. Teknik sampling yang digunakan adalah total sampling. Instrumen menggunakan kuisener dan analisa menggunakan Regresi logistik pada sisnifikan $5 \%$.

\section{HASIL DAN PEMBAHASAN \\ Hasil Penelitian}

Gambaran tentang responen sebagai berikut:

Tabel 1. Distribusi Frekuensi Latar belakang pendidikan SMA IPA dengan Prestasi Belajar Mahasiswa

\begin{tabular}{cccc}
\hline No & Kategori & Frekuensi & Prosentase \\
\hline 1 & Baik & 23 & $100,0 \%$ \\
2 & Kurang & - & $0 \%$ \\
\hline & Jumlah & 23 & $100 \%$ \\
\hline
\end{tabular}

Data ini menunjukkan bahwa mahasiswa yang berprestasi baik yaitu sebesar $100 \%$ dari total mahasiswa yang berlatar pendidikan SMA IPA. Hal ini dimungkinkan adanya pengalaman belajar sebelumnya yang mempengaruhi mereka dalam proses pembelajaran.

Tabel 2. Distribusi Frekuensi Latar Belakang pendidikan SMA IPS dengan Prestasi Belajar Mahasiswa

\begin{tabular}{cccc}
\hline No & Kategori & Frekuensi & Prosentase \\
\hline 1 & Baik & 30 & $93,75 \%$ \\
2 & Kurang & 2 & $6,25 \%$ \\
\hline & Jumlah & 32 & $100 \%$ \\
\hline
\end{tabular}

Data ini menunjukkan bahwa mayoritas mahasiswa dengan latar pendidikan SMA IPS berprestasi baik yaitu sebesar 93,75\% meskipun ada beberapa mahasiswa yang mempunyai prestasi kurang baik sebesar 6,25\%. Bagi mahasiswa yang kurang berprestasi dimungkinkan adanya faktor-faktor lain yang mempengaruhi mereka dalam meraih prestasi.

\section{Tabel 3. Distribusi Frekuensi Latar Belakang pendidikan SMK dengan Prestasi Belajar Mahasiswa}

\begin{tabular}{cccc}
\hline No & Kategorik & Frekuensi & Prosentase \\
\hline 1 & Baik & 11 & $73,33 \%$ \\
2 & Kurang & 4 & $26,66 \%$ \\
\hline & Jumlah & 15 & $100 \%$ \\
\hline
\end{tabular}

Data di atas menunjukkan bahwa mahasiswa dengan latar belakang pendidikan SMK mayoritas masih ada yang berprestasi baik yaitu 
sebesar 73,33 \% dari total mahaiswa yang berlatar belakang pendidikan SMK, meskipun ada beberapa mahasiswa yang mempunyai prestasi kurang baik yaitu 26,66 \%. Ada beberapa faktor yang dimungkinkan mempengaruhi mereka dalam meraih prestasi yaitu minat dan motivasi belajar dan proses pemahaman dalam proses pembelajaran.

Tabel 4. Distribusi Frekuensi Latar Belakang Pendidikan dengan Prestasi Belajar Mahasiswa

\begin{tabular}{ccccc}
\hline \multirow{5}{*}{ No } & \multirow{4}{c}{ Kategori } & \multicolumn{2}{c}{ Belajar } & Jumlah \\
& & Baik & Kurang & \\
\hline \multirow{2}{*}{1} & \multirow{2}{*}{ SMA IPA } & 23 & 0 & 23 \\
& & $(100 \%)$ & & $(100 \%)$ \\
2 & SMA IPS & 30 & 2 & 32 \\
& & $(93,8 \%)$ & $(6,25 \%)$ & $(100 \%)$ \\
3 & \multirow{2}{*}{ SMK } & 11 & 4 & 15 \\
& & $(73,3 \%)$ & $(26,7 \%)$ & $(100 \%)$ \\
\hline \multirow{4}{*}{ Jumlah } & 64 & 6 & 70 \\
& & $(91,4 \%)$ & $(8,57 \%)$ & $(100 \%)$ \\
\hline
\end{tabular}

Dari data di atas menunjukkan bahwa latar pendidikan SMA IPA yang mempunyai prestasi baik sebesar $100 \%$ dari keseluruhan jumlah siswa berlatar belakang pendidikan SMA IPA. Dan latar belakang pendidikan SMA IPS yang berprestasi baik mencapai 93,75\% dengan yang berprestasi kurang 6,25 \%. Sedangkan yang berlatar belakang pendidikan SMK dengan prestasi yang baik hanya $73,33 \%$ dan yang mempunyai prestasi kurang mencapai $26,67 \%$. Dengan demikian prestasi yang baik didominasi oleh mahasiswa yang berlatar belakang pendidikan SMA IPA dan SMA IPS. dengan tidak adanya prestasi yang kurang dibanding kedua jenjang pendidikan yaitu SMA IPS sebesar $42,86 \%$ dengan prestasi yang kurang sebesar $2,86 \%$ dan SMK sebesar 15,71 \% dengan prestasi yang kurang sebesar $5,71 \%$. Rendahnya prestasi atau prestasi yang kurang baik pada kedua latar belakang pendidikan yaitu SMA IPS $(6,25 \%)$ dan SMK $(26,67 \%)$ dimungkinkan adanya tingkat pemahaman materi pembelajaran yang sedikit berbeda atau sama sekali baru yang diterimanya. Dan juga berkaitan dengan pengalaman pembelajaran pada saat menempuh pendidikan sebelumnya.
Tabel 5. Distribusi Frekuensi Motivasi Belajar dengan Prestasi Belajar Mahasiswa

\begin{tabular}{|c|c|c|c|c|}
\hline \multirow[t]{2}{*}{ No } & \multirow{2}{*}{ Kategori } & \multicolumn{2}{|c|}{$\begin{array}{c}\text { Frekuensi Prestasi } \\
\text { Belajar }\end{array}$} & \multirow{2}{*}{ Jumlah } \\
\hline & & Baik & Kurang & \\
\hline 1 & Tinggi & $\begin{array}{c}40 \\
(57,1 \%)\end{array}$ & $\begin{array}{c}1 \\
(1,4 \%)\end{array}$ & $\begin{array}{c}41 \\
(58,6 \%)\end{array}$ \\
\hline 2 & Sedang & $\begin{array}{c}24 \\
(34,3 \%)\end{array}$ & $\begin{array}{c}3 \\
(439 \%)\end{array}$ & $\begin{array}{c}27 \\
(38,6 \%)\end{array}$ \\
\hline \multirow[t]{2}{*}{3} & Rendah & 0 & $\begin{array}{c}2 \\
(2,9 \%)\end{array}$ & $\begin{array}{c}2 \\
(2,86 \%)\end{array}$ \\
\hline & Jumlah & $\begin{array}{c}64 \\
(91,4 \%)\end{array}$ & $\begin{array}{c}6 \\
(8,6 \%)\end{array}$ & $\begin{array}{c}70 \\
(100 \%)\end{array}$ \\
\hline
\end{tabular}

Berdasarkan data di atas bahwa prestasi belajar yang paling baik yang mempunyai kategori motivasi tinggi yaitu sebesar 57,14 \% dan yang mempunyai motivasi rendah dengan prestasi kurang baik sebesar 2,86\%. Hal ini menunjukkan bahwa motivasi belajar mahasiswa sangat tinggi dalam meraih prestasi belajar, meskipun ada beberapa mahasiswa mempunyai motivasi belajar sedang-sedang dengan prestsi baik yaitu sebesar 34,29\%. Motivasi yang tinggi dapat menumbuhkan semangat belajar dan meraih sukses sesuai yang diharapkan.

Tabel 6. Variabel Motivasi Belajar

\begin{tabular}{ccc}
\hline Motivasi Belajar & Frekuensi & Persentase (\%) \\
\hline Rendah & 2 & 2,86 \\
Sedang & 27 & 38,57 \\
Tinggi & 41 & 58,57 \\
\hline Jumlah & 70 & 100 \\
\hline
\end{tabular}

Tabel di atas sebagian besar responden mempunyai motivasi belajar yang tinggi yaitu sebesar $58,57 \%$, sedang $38,57 \%$ dan rendah $2,86 \%$.

Tabel 7. Variabel Latar Belakang Pendidikan

\begin{tabular}{ccc}
\hline Pendidikan & Frekuensi & Persentase $(\%)$ \\
\hline SMK & 15 & 21.40 \\
SMA IPS & 32 & 45.70 \\
SMA IPA & 23 & 32.90 \\
\hline Jumlah & 70 & 100 \\
\hline
\end{tabular}

Tabel 7 menunjukkan bahwa sebagian besar responden berpendidikan SMA IPS sebesar 45,70\%, SMA IPA 32,90\%, dan SMK sebesar $21,40 \%$. 
Tabel 8. Variabel Prestasi Belajar

\begin{tabular}{ccc}
\hline Prestasi Belajar & Frekuensi & Persentase \\
\hline Kurang & 6 & 8.60 \\
Baik & 64 & 91.40 \\
\hline Jumlah & 70 & 100.00 \\
\hline
\end{tabular}

Dari tabel di atas sebagian besar prestasi responden adalah baik yaitu sebesar $91.40 \%$, dan prestasi kurang sebesar $8.60 \%$.

Hasil Analisa Logistik Regresi

Dari hasil perhitungan dengan program SPSS maka dapat ditabulasikan sebagai berikut:

Tabel 9. Model Summary

\begin{tabular}{crrr}
\hline Step & $\begin{array}{c}-2 \text { Log } \\
\text { likelihood }\end{array}$ & $\begin{array}{c}\text { Cox \& Snell } \\
\text { R Square }\end{array}$ & $\begin{array}{c}\text { Nagelkerke } \\
\text { R Square }\end{array}$ \\
\hline 1 & $24.662(a)$ & .208 & .469 \\
\hline
\end{tabular}

Dari hasil analisis data dapat dilihat bahwa nilai Cox dan Snell's $\mathrm{R}^{2}$ sebesar 0,208 dan nilai Negelkerke $\mathrm{R}^{2}$ sebesar 0,469 yang berarti variabel dependent dijelaskan oleh variabel independent sebesar 46,90\%.

Tabel 10. Hosmer and Lemeshow Test

\begin{tabular}{crrr}
\hline Step & Chi-square & df & \multicolumn{1}{c}{ Sig. } \\
\hline 1 & .991 & 4 & .911 \\
\hline
\end{tabular}

Hosmer and Lemeshow Test menguji hipotesis nol bahwa data empiris cocok atau sesuai dengan model (tidak ada perbedaan antara model dengan data sehingga model dapat dikatakan fit). Jika nilai Hosmer and Lemeshow Test sama dengan atau kurang dari 0.05, maka hipotesis nol ditolak yang berarti ada perbedaan yang signifikan antara model dengan nilai observasinya sehingga Goodness fit model tidak baik karena model tidak dapat memprediksi nilai observasinya. Jika Hosmer and Lemeshow Test lebih besar dari 0.05 maka hipotesis nol tidak dapat ditolak dan berarti model mampu memprediksi nilai observasinya atau dapat dikatakan model dapat diterima karena cocok dengan observasinya. Tabel diatas menunjukkan bahwa besarnya nilai statistic Hosmer and Lemeshow sebesar 0,991 dengan probabilitas signifikansi 0.911 yang nilainya lebih besar dari 0.05 , dengan demikian dapat disimpulkan bahwa model dapat diterima.

Tabel 11. Estimasi Parameter Regresi

\begin{tabular}{|c|c|c|c|c|c|c|}
\hline \multicolumn{7}{|c|}{ Variables in the Equation } \\
\hline & $B$ & S.E. & Wald & $d f$ & Sig. & $\operatorname{Exp}(B)$ \\
\hline Stap $x 1$ & 2.401 & 1.093 & 4.821 & 1 & .028 & 11.032 \\
\hline $1 \times 2$ & 1.937 & .937 & 4.267 & 1 & .039 & 6.935 \\
\hline Constant & -6.496 & 2.932 & 4.910 & 1 & .027 & .002 \\
\hline
\end{tabular}

Tabel 11. menunjukkan estimasi maksimum likehood parameter dan dapat dinyatakan sebagai berikut:

$$
\operatorname{Ln} \frac{P}{1-P}=-0.496+2.401 X 1+1.937 X 2
$$

Motivasi dan pendidikan berpengaruh signifikan terhadap prestasi belajar siswa karena mempunyai nilai $P$ value $<0,05$. Dari persamaan logistic regression di atas dapat dilihat bahwa $\log$ off odds prestasi belajar akan lebih tinggi secara positif berhubungan dengan motivasi belajar siswa dan latar belakang pendidikan. Setiap unit kenaikan motivasi belajar akan meningkatkan $\log$ of odds prestasi belajar sebesar 2,401 dan setiap unit perubahan latar belakang pendidikan akan meningkat $\log$ of odds prestasi belajar sebesar 1,937 .

Hubungan antara odds dari variabel bebas dapat dijelaskan sebagai berikut: jika latar belakang pendidikan dianggap konstan, maka odds prestasi belajar mahasiswa akan naik dengan expected. ( $\beta$ ) 11,032 untuk setiap kenaikan unit motivasi belajar, yang berarti prestasi belajar mahasiswa yang baik adalah 11,032 kali untuk motivasi belajar tinggi dibanding motivasi belajar sedang dan rendah dengan nilai $P$ value 0,028 ( $P$ value $<0,05)$. Ini berarti bahwa ada hubungan antara motivasi belajar dengan prestasi belajar mahasiswa. Sedangkan variabel X1 (motivasi belajar) dianggap konstan, maka odds prestasi belajar akan naik dengan expected ( $\beta$ ) 6,935 untuk setiap perubahan unit latar belakang pendidikan dengan nilai $P$ value 0,039 ( $P$ value $<0,05)$. Hal ini berarti ada hubungan antara latar belakang pendidikan dengan prestasi belajar mahasiswa. 


\section{Pembahasan}

Motivasi belajar berpengaruh secara signifikan terhadap prestasi belajar mahasiswa, hasil pada table 15. menunjukkan bahwa setiap unit kenaikan motivasi belajar (X1) akan meningkatkan log of odds prestasi belajar sebesar 2,401 dengan expected 11,032 kali. Sehingga dapat dikatakan sebagian besar mahasiswa mempunyai motivasi tinggi. Hal ini didukung oleh Santrock dalam Sardiman (2007) bahwa motivasi adalah proses yang memberi semangat, arah, dan kegigihan perilaku. Artinya perilaku yang memiliki motivasi adalah perilaku yang penuh energi, terarah dan bertahan lama. Dan Uno (2009) mengatakan bahwa motivasi sangatlah penting bagi seseorang untuk menentukan tindakan seseorang dalam meraih sesuatu yang diinginkan karena akan memberikan kekuatan pada diri individu dan motivasi sangat berpengaruh terhadap ketahanan dan ketekunan belajar. Untuk mencapai tujuan yaitu prestasi belajar.

Di Akademi Keperawatan Patria Husada Surakarta, motivasi belajar mahasiswa rata-rata tinggi hal ini dipengaruhi oleh keinginan mahasiswa dalam meraih cita-cita menjadi perawat yang profesionl dan berhasil sesuai batas studinya. Selain dari unsur dalam diri mahasiswa ada unsur pendukung lain yang berperan dalam meningkatkan motivasi belajar mahasiswa yaitu kemampuan dosen dalam mengajar, materi pembelajaran, metode pengajaran yang menarik dan mudah dipahami yang disertai dengan sarana dan prasarana serta lingkungan yang kondusif baik fisik dan biologi. Hal ini sesuai dengan yang disampaikan oleh Pujadi (2007) dalam penelitiannya bahwa faktor-faktor yang diduga memiliki hubungan motivasi belajar mahasiswa empat diantaranya yaitu faktor intrinsik dalam diri mahasiswa, kualitas dosen, bobot materi kuliah dan metode perkuliahan. Dan prestasi belajar sendiri dipengaruhi oleh beberapa hal yang berkaitan dengan diri individu selain motivasi yaitu kesehatan, cara belajar, kecerdasan, bakat, dan minat. Dan juga didukung oleh Slameto (2003) bahwa faktor-faktor internal itu antara lain (1) Kesehatan, kesehatan jasmani dan rohani sangat besar pengaruhnya terhadap kemampuan belajar. Siswa yang kesehatannya baik akan lebih mudah dalam belajar dibandingkan dengan siswa yang kondisi kesehatannya kurang baik, sehingga hasil belajarnya juga akan lebih baik. (2) Kecerdasan/intelegensia, kecerdasan/intelegensia besar pengaruhnya dalam menentukan seseorang dalam mencapai keberhasilan. Seseorang yang memiliki intelegensi yang tinggi akan lebih cepat dalam menghadapi dan memecahkan masalah, dibandingkan dengan orang yang memiliki intelegensi rendah. Dengan demikian intelegensi memegang peranan dalam keberhasilan seseorang untuk mencapai tujuan yang diinginkan. Demikian pula dalam prestasi belajar. Siswa yang memiliki kecerdasan tinggi, prestasi belajarnya juga akan tinggi, sementara siswa yang memiliki intelegensia rendah maka prestasi yang diperoleh juga akan rendah. (3) Cara belajar, cara belajar seseorang mempengaruhi pencapaian hasil belajarnya. Belajar tanpa memperhatikan teknik dan faktor fisiologis, psikologis dan ilmu kesehatan akan memperoleh hasil yang kurang memuaskan. (4) Bakat, bakat adalah kemampuan potensial yang dimiliki seseorang untuk mencapai keberhasilan pada masa yang akan datang. Siswa yang belajar sesuai dengan bakatnya akan lebih berhasil dibandingkan dengan orang yang belajar di luar bakatnya. (5) Minat, seorang siswa yang belajar dengan minat yang tinggi maka hasil yang akan dicapai lebih baik dibandingkan dengan siswa yang kurang berminat dalam belajar. (6) Motivasi, motivasi sebagai faktor intern berfungsi menimbulkan, mendasari, mengarahkan perbuatan belajar. Dengan adanya motivasi maka siswa akan memiliki prestasi yang baik, begitu pula sebaliknya.

Latar belakang pendidikan mahasiswa berpengaruh signifikan terhadap prestasi belajar mahasiswa. Jenjang pendidikan adalah tahapan pendidikan yang ditetapkan berdasarkan tingkat perkembangan peserta didik, tujuan yang akan dicapai dan kemampuan yang dikembangkan. Latar belakang pendidikan masuk pada sebuah jurusan di perguruan tinggi merupakan modal utama dalam mengikuti dan memahami mata kuliah tertentu. Hasil logistic regression pada tabel 15. menunjukkan bahwa odds ratio prestasi belajar akan naik setiap pada perubahan latar belakang pendidikan yaitu sebesar ( $\beta$ ) 1,937 dengan expected ( $\beta$ ) 6,935.

Jenjang pendidikan yang mempunyai kurikulum pendidikan dengan materi pengajaran ilmu pengetahuan alam sangat mendukung keberhasilan proses pendidikan di Akademi Keperawatan, yaitu jenjang SMA, SMK Kesehatan dan SMK Kimia Industri. Namun demikian pengalaman belajar juga merupakan suatu hal yang penting sebagai dasar dalam memahami mata pelajaran yang sedang ditempuhnya. Hal ini 
sesuai dengan yang disampaikan Slameto (2003) bahwa belajar sebagai suatu proses usaha yang dilakukan seseorang untuk memperoleh suatu perubahan tingkah laku yang secara keseluruhan, sebagai hasil pengalamannya sendiri dalam interaksi dengan lingkungannya.

Namun demikian dalam pencapaian prestasi belajar, mahasiswa masih mengalami kesulitan pemahaman materi terutama mereka yang berlatar belakang pendidikan dari non SMA. Sehingga mereka yang mampu mencapai prestasi baik adalah mereka yang berlatar belakang pendidikan SMA IPA dan sebagian besar dari SMA IPS. Walaupun sebagian kecil dari mereka yang berlatar belakang pendidikan non SMA (SMK non Kesehatan) ada yang dapat mencapai prestasi yang memuaskan.

Hubungan antara motivasi belajar dan atar belakang pendidikan dengan prestasi dapat dijelaskan bahwa variabel X1 (motivasi) dan variabel X2 berpengaruh signifikan terhadap prestasi belajar siswa (Y) karena masing-masing variabel independen mempunyai nilai $P$ value < 0,05 . Dari persamaan logistic regression pada tabel 15. di atas dapat dilihat bahwa log off odds prestasi belajar (Y) akan lebih tinggi secara positif berhubungan dengan motivasi belajar siswa (X1) dan latar belakang pendidikan (X2). Motivasi yang tinggi dengan latar belakang pendidikan yang mendukung proses pembelajaran akan mempermudah mahasiswa dalam mencapai prestasi yang lebih baik. Sebaliknya latar belakang pendidikan yang kurang mendukung akan menggambarkan prestasi yang kurang memuaskan dalam proses pembelajaran. Seperti disampaikan oleh Uno (2009) bahwa motivasi sangatlah penting bagi seseorang untuk menentukan tindakan seseorang dalam meraih sesuatu yang diinginkan karena akan memberikan kekuatan pada diri individu. Motivasi sangat berpengaruh terhadap ketahanan dan ketekunan belajar.

Sedangkan factor eksternal yaitu kualitas dosen dalam memberikan pembelajaran memberikan arti tersendiri untuk mendukung kemampuan mahasiswa dalam mencapai tujuan pembelajaran yaitu prestasi belajar. Hal ini sesuai pendapat Arko Pujadi dalam penelitiannya bahwa empat factor yang memiliki hubungan dalam motivasi belajar mahasiswa adalah factor internal mahasiswa, kualitas dosen, bobot materi kuliah,dan metode perkuliahan terbukti memiliki hubungan yang signifikan.

\section{KESIMPULAN}

Penelitian terhadap 70 responden terhadap mahasiswa Akademi Keperawatan Patria Husada Surakarta bahwa

1. Ada hubungan yang signifikan antara motivasi belajar dengan prestasi belajar mahasiswa, jika variabel X2 (latar belakang pendidikan) dianggap konstan, maka odds prestasi belajar mahasiswa akan naik dengan expected. ( $\beta$ ) 11,032 untuk setiap kenaikan unit X1 (motivasi belajar), yang berarti prestasi belajar mahasiswa yang baik adalah 11,032 kali untuk motivasi belajar tinggi dibanding motivasi belajar sedang dan rendah. Berarti bahwa makin tinggi motivasi belajar mahasiswa maka makin tinggi pula pencapaian prestasi belajar mahasiswa.

2. Ada hubungan yang signifikan antara latar belakang pendidikan dengan prestasi belajar mahasiswa, jika variabel X1 (motivasi belajar) dianggap konstan, maka odds prestasi belajar akan naik dengan expected ( $\beta$ ) 6,935 untuk setiap perubahan unit X2 (latar belakang pendidikan). Berarti latar beakang pendidikan SMA IPA dan SMA IPS mempunyai kontribusi lebih baik dibandingkan dengan mahasiswa yang berlatar belakang pendidikan SMK.

3. Ada hubungan yang signifikan antara latar belakang pendidikan dan motivasi belajar dengan prestasi belajar mahasiswa di Akademi Keperawatan Patria Husada Surakarta, karena variabel X1 (motivasi) dan variable $\mathrm{X} 2$ berpengaruh signifikan terhadap prestasi belajar siswa (Y) karena masingmasing variabel independent mempunyai nilai $P$ value $<0,05$. Dari persamaan logistic regression di atas dapat dilihat bahwa log off odds prestasi belajar (Y) akan lebih tinggi secara positif berhubungan dengan motivasi belajar siswa (X1) dan latar belakang pendidikan (X2). Setiap unit kenaikan motivasi belajar (X1) akan meningkatkan $\log$ of odds prestasi belajar sebesar 2,401 dan setiap unit perubahan latar belakang pendidikan (X2) akan meningkat log of odds prestasi belajar sebesar 1,937. Artinya bahwa motivasi yang baik dengan latar belakang pendidikan SMA memberikan kontribusi yang baik dibandingkan dengan yang berlatar belakang pendidikan SMK. 


\section{SARAN}

Motivasi belajar merupakan modal dasar dalam meraih prestasi akademik, maka dari itu diharapkan mahasiswa membangun motivasi diri dalam berkompetisi untuk meraih prestasi dengan meningkatkan tehnik belajar yang efektif. Pengembangan pendidikan selanjutnya diharapkan adanya pendampingan terhadap mahasiswa untuk menumbuhkan motivasi belajar mahasiswa dalam bentuk mentoring sehingga mahasiswa yang mempunyai masalah dengan prestasinya dapat diakomodasi dan difasilitasi dengan baik. Bentuk pendampingan dapat berupa latihan laboratorium, diskusi kelompok dan penugasan yang membantu pengembangan diri mahasiswa dalam mencapai prestasi belajarnya.

Pendidikan yang berhasil tidak lepas dari sumber daya yang baik. Dengan sumber daya yang baik diharapkan peserta didik dapat menikmati proses pembelajaran yang memuaskan sehingga pencapaian prestasi yang maksimal dapat diraih oleh mahasiswa dengan memuaskan pula. Oleh karena itu diharapkan peningkatan sumber daya manusia utamanya bidang pendidikan akan meningkatkan kualitas lulusan yang lebih baik. Kualitas dosen pengampu menentukan tingkat pemahaman mahasiswa dalam mengikuti proses pembelajaran. Untuk itu peningkatan tehnik dalam mengajar dengan mengikuti berbagai pelatihan akan memberikan kontribusi yang tinggi terhadap prestasi belajar.

Dari hasil penelitian ini diketahui bahwa variabel motivasi belajar mahasiswa merupakan variabel yang paling dominan, oleh karena itu disarankan kepada institusi pendidikan terkait untuk memperhatikan variabel motivasi belajar mahasiswa dengan cara menanamkan rasa kepercayaan diri mahasiswa akan harapan dan cita-citanya dalam meraih sukses dikemudian hari. Dan variabel latar belakang pendidikan juga berpengaruh besar pada keberhasilan mahasiswa maka disarankan dalam penerimaan mahasiswa baru untuk memperhatikan latar belakang pendidikan yang sesuai dalam hal ini latar belakang pendidikan SMA atau jika diperlukan adanya matrikulasi untuk membantu mahasiswa dalam mempersiapkan diri menempuh pendidikan.

\section{DAFTAR PUSTAKA}

Pujadi, A. 2005. Fakto-faktor Yang Mempengaruhi Motivasi Belajar Mahasiswa: Studi Kasus Pada Fakultas Ekonomi Universitas Bunda Mulia. www.jurnalar kopujadi.com

Purwanto, MN. 2007. Psikologi Pendidikan. Bandung: PT. Remaja Rosdakarya.

Sardiman, AM. 2007. Interaksi dan Motivasi Belajar Mengajar. Jakarta: PT. Raja Grafindo Persada.

Sairin, W. 2010. Himpunan Peraturan Dibidang Pendidikan. Jakarta: Jala Permata Aksara.

Sari, BN. 2004. Sistem Pembelajaran KBK Terhadap Motivasi Belajar Para Peserta Didik Pada Bidang Studi Fisika.www.researchengine.com.

Uno, HB. 2006. Teori motivasi dan Pengukurannya: Analisis di Bidang Pendidikan. Jakarta: PT. Bumi Aksara. 